\title{
Philosophy and Critical Theory \\ Shining a light on Saladdin Ahmed's research
}
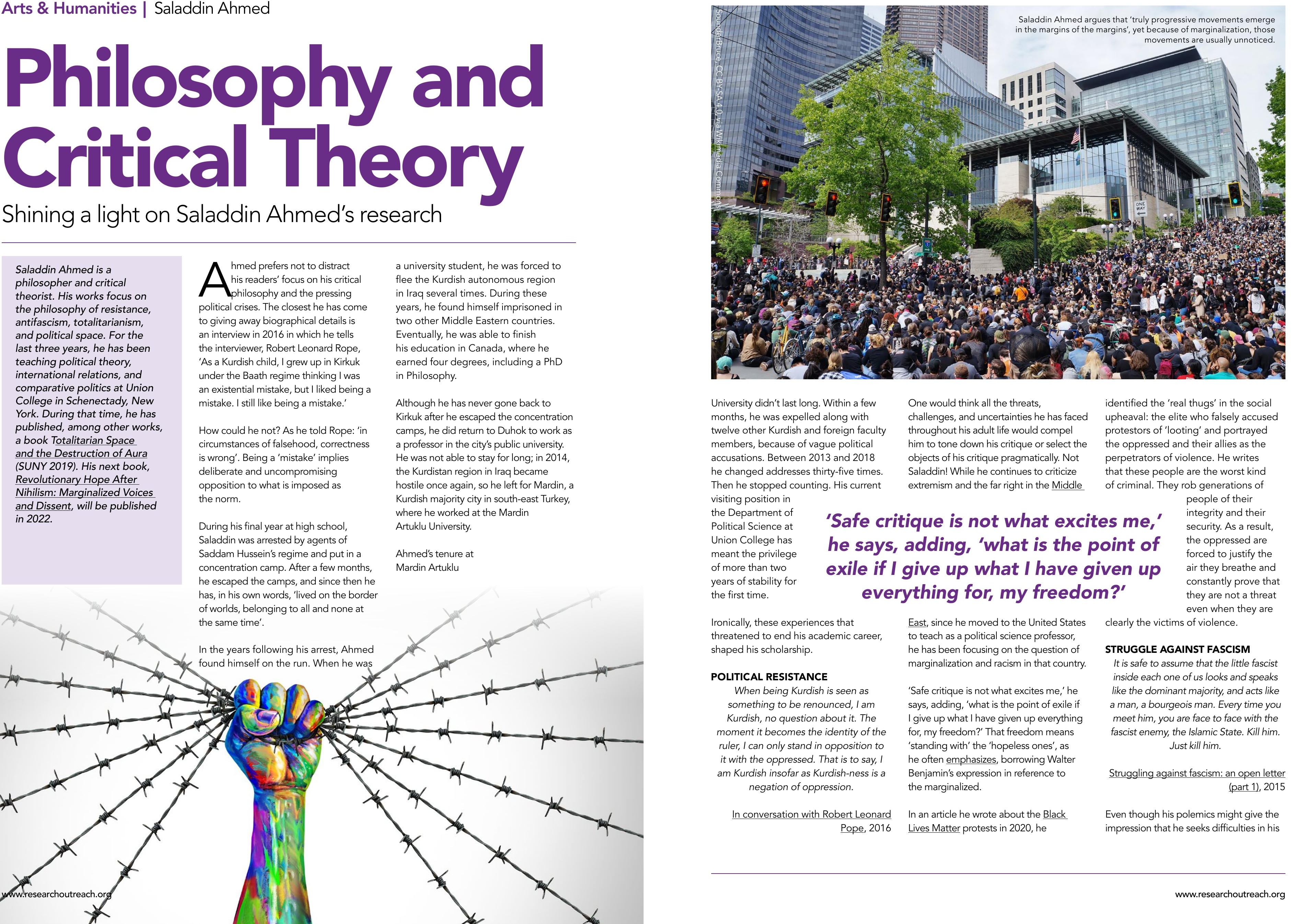

University didn't last long. Within a few months, he was expelled along with twelve other Kurdish and foreign faculty members, because of vague political accusations. Between 2013 and 2018 he changed addresses thirty-five times. Then he stopped counting. His curre visiting position in the Department of Political Science at Union College has meant the privilege years of stability for the first time.

'Safe critique is not what excites me,' he says, adding, 'what is the point of exile if I give up what I have given up everything for, my freedom?'

Ironically, these experiences that threatened to end his academic caree, shaped his scholarship.

\section{POLITICAL RESISTANCE}

When being Kurdish is seen as something to be renounced, I am Kurdish, no question about it. The moment it becomes the identity of the ruler, I can only stand in opposition to it with the oppressed. That is to say, I Kurdish insofar as Kurdish-ness
negation of oppression.

In conversation with Robert Leonard Pope, 2016
One would think all the threats, challenges, and uncertainties he has faced ult life would compel him to toned Saladdin! While he continues to critiz identified the 'real thugs' in the social upheaval: the elite who falsely accused protestors of "looting" and portrayed the oppressed and their allies as the perpetrators of violence. He writes

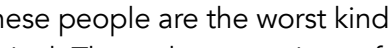
people of their integrity and their security. As a result, the oppressed are forced to justify the air they breathe and they are not a threat they are not a threat

East, since he moved to the United States to teach as a political science professor, marginalization and racism in that coun

'Safe critique is not what excites me,' he says, adding, 'what is the point of exile Igive up what thave given up everything for, my freedom? That freedom means 'standing with' the 'hopeless ones', as he often emphasizes, borrowing Walter Benjamin's expression in reference to

In an article he wrote about the Black Lives Matter protests in 2020, he clearly the victims of violence. It is safe to assume that the little fascist inside each one of us looks and speaks majority, and acts like you are face to face with the Just kill him.
.

Struggling against fascism: an open lette (part 1), 2015

Even though his polemics might give the mpression that he seeks difficulties in his
STRUGGLE AGAINST FASCISM 


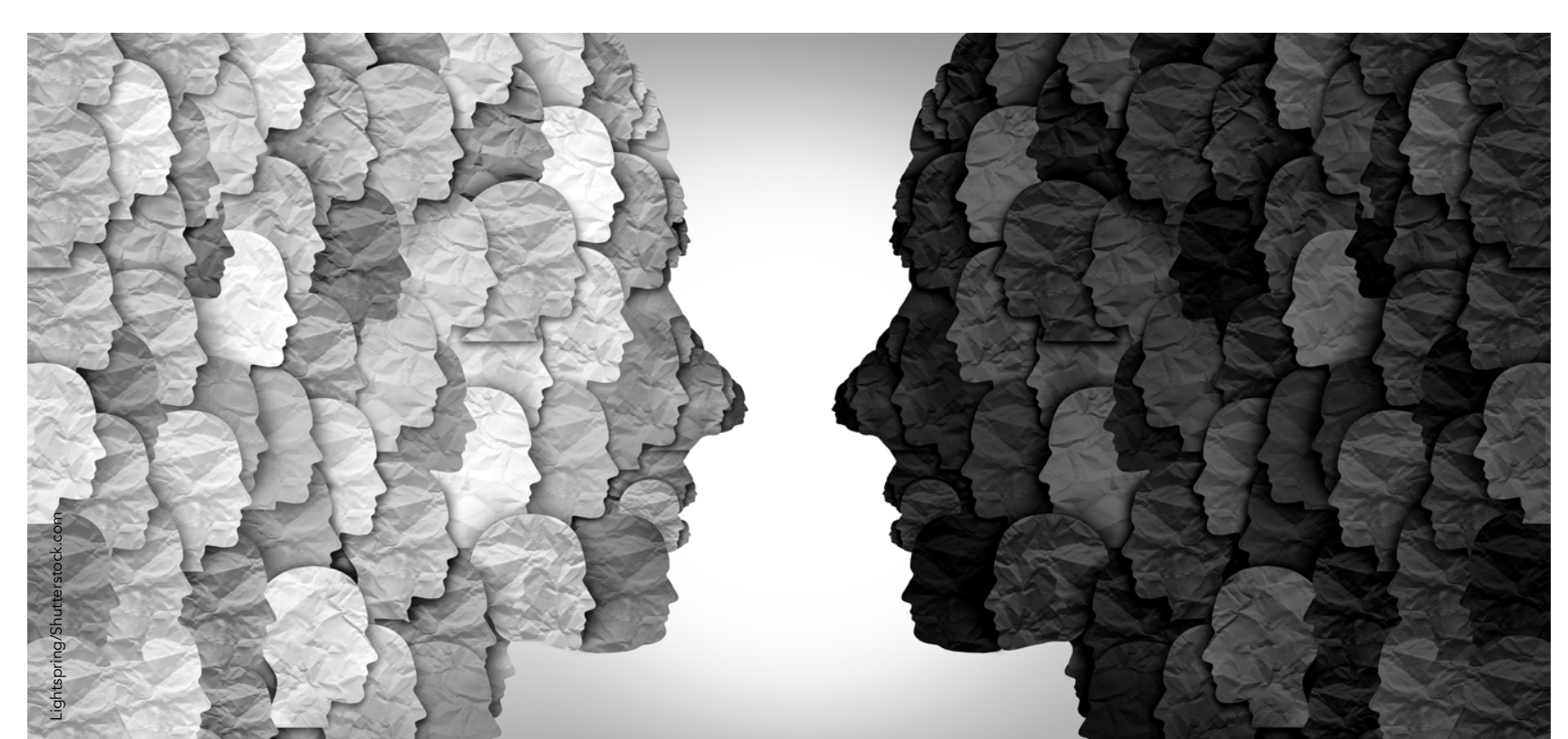
personal. No matter where he is, Ahmed life, in reality the issue is anything but believes that it is his responsibility as of fascists and reveal the enablers of fascism everywhere.

At points in his life, this has meant warning his students in Iraq and Syria against succumbing to the appeal of faith over reason, which is the san fallacy that created ISIS. In the United States, this has included highlighting the prejudice hidden in plain sight allowing for the commodification of oppressed social groups. He rejects what he sees as 'exclusion through inclusion', and his example for that is the common practice of posting a picture of a few'smiling websites. To him, this practice merely commodifies, objectifies, and others those who have already been raced.

or uniqueness is mass produced, and, (a) hegemony This book, and the author's philosophy of negativity in general, often give rise to two typical questions Saladd continually has to address even in his lectures. Those questions have to do with the plausibility of an alternative and the

\section{TAKING THE SIDE OF THE SILENCED} One does not need to look afar to realize that humanity owes so much of its progress to those very peoples marginalized so brutally for so long.

Struggling against fascism: an open letter $(\operatorname{lop} 2), 2020$

'every hegemonic ideology as a matter of course presents itself as something other truth that is above and beyond human conditions and their histories, conflicts and struggles. Whereas no matter how rational the voice of the marginalized that demands equality, it is perceived as a subjective and bias voice'.

The struggle for him as a critical educator as he describes it, is to problematize the convictions of objectivity, to shake 'the dominant mode of perception', to draw students' attention to the fact that in every society and historical era, the dominant not only refuses to portray problems, but also croartes a wem of all which the buting ideolegy is the most

Saladdin calls his philosophy sensical, and rationa "postnihilism," and it constantly eventhing. Thus, emphasizes the revolutionary hope of education is learning those in the margins of the margins. Lia unlearning.

In Totalitarian Space place of hope in his philosophical system. and the Destruction of Aura, he defines totalitarianism by deploying a negative method. Namely, he aims to point out what is being destroyed in the process answer to that is aura. Conceptualizing aura as the spatial conditions for unique experiences, he shows the ways in which totaltanianism leads to the creation of a space of total flatness, ilumination, and
isolation. In such a space, even identity of the construction of totalitarianism.
Taking the side of the silenced, marginalized, and underrepresented characterizes Saladdin's philosophy. Even as an educator, he argues since all positions are necessarily subjective, the difference is in the way knowledge is produced, and by that he means 'in whose interest?' Those who insis on being non-ideological, Saladdin the ides, are in fact in the first class of pedagogy is constructed around what he calls 'negativity'.

Saladdin calls his philosophy 'postrihilism', and it constantly emphasizes the revolutionary hope of those in the margins of the margins. progressive movements emerge in the margins of me mems', yet because of In a 2019 article, he argues that 'truly

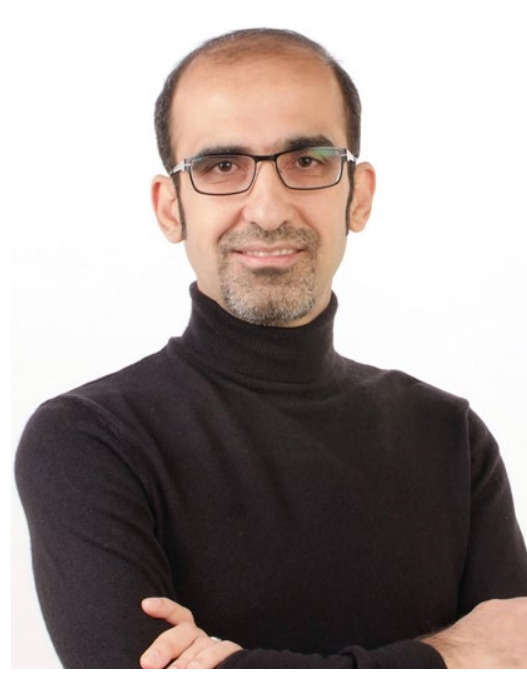

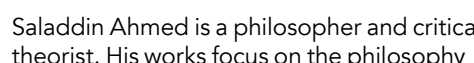
theorist. His works focus on the philosophy
of resistance, antifascism, totalitarianism, and political space.

usually unnoticed. 'Indeed', he goes on, the world owes much of its progress to so brutally for so long' 'This is also why even when it comes to the Arab Spring in his view, the movements that have been largely dismissed by the world, such as Rojava and Sudan, are the most significant ones

To the question of 'what is the solution?' his response is swift. Let us not jump to a solution before we accurately comprehend the nature and scope of the crises. The primary task of critical philosophy is to point to the right questions.' Otherwise, he continues, 'we repeatedly provide wrong answers to wrong questions. Inspired by Theodor published in 2020 , Ahmed writes, is neither a green way of living under capitalism nor an unrevolutionay way ou of capitalism.' (p134).

Saladdin ends his 2019 book stating, 'Human societies have already invented so many forms of oppression that the mere negation of those forms should put us well on our way to the realization of a world that would be fair and just by all conceivable standards. By climbing atop the heap of garbage that has accumulated over the course of civilization, we should begin to see a horizon never before seen. (p178). Thi stems from his 'dialects of hope and topic of his upcoming book.

\section{References}

Ahmed, S, (2016) Being a Kurdish-Turkish mistake. Open Democracy, www. opendemocracy.net/en/being-kurdish-turkish-mistake

Ahmed, S, (2020) The Jerusalem Post, www.jpost.com/blogger/saladdinahmed

Ahmed, S, (2020) Reimagining a World where Justice is Possible. Institute for Social Ecology. social-ecology.org/wp/2020/06/reimagining-a-worldwhere-justice-is-possible

YouTube (2021) Universal University? On Space and Inclusion in Higher Education: A conversation with Saladdin Ahmed. SFU Morris J. V/osk Centre for Dialogue.

Ahmed, S, (2015) Struggling against fascism: an open letter. Open Democracy, www.opendemocracy.net/en/can-europe-make-it/strugglingagainst-fascism-second-open-letter

Ahmed, S, (2020) Struggling against fascism: second open letter. Open Democracy, www.opendemocracy.net/en/can-europe-make-it/strugglingagainst-fascism-second-open-letter

Ahmed, S, (2019) The Left's Culturalism and Rojava. Contours Journal, www. academia.edu/43725266/The_Lefts_Culturalism_and_Rojava

Ahmed, S, (2014) 'Rojava is the only region in the world where women have organized themselves to ideologically and physically fight Islamist forces', Your Middle East, yourmiddleeast.com/2014/05//2/rojava-is-the-
only-region-in-the-world-where-women-have-organized-themselves-toideologically-and-physically-fight-islamist-forces

Ahmed, S, (2019) The Significance of the Sudanese Revolution. TELOSscope, www.telospress.com/the-significance-of-the-sudanese revolution

Ahmed, S, (2020) The Ecological Crisis, Apocalypticism, and the Economy, 11(1) $115-140$

Ahmed, S, (2019) Totalitarian Space and the Destruction of Aura. SUNY Press, www.sunypress.edu/p-6707-totalitarian-space-and-the-dest.aspx

Ahmed, S, (2022) Revolutionary Hope After Nihilism: Marginalized Voices Dissent. Bloomsbury Publishing. Revolutionary Hope After Nihilism: Marginalized Voices and Dissent: Saladdin Ahmed: Bloomsbury Academic

UNION

C O L L E G

FOUNDED 1795
E: saladdin.ahmed@gmail.com E: ahmeds2@union.edu W: saladdinahmed.com 